\title{
EON
}

\section{President's Farewell}

\section{Erin Landis ${ }^{1}$}

${ }^{1}$ Vice President, Publications, American Gastroenterological Association

Published on: Jan 05, 2022

License: Creative Commons Attribution 4.0 International License (CC-BY 4.0). 


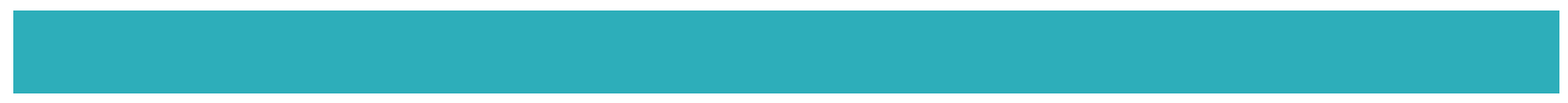

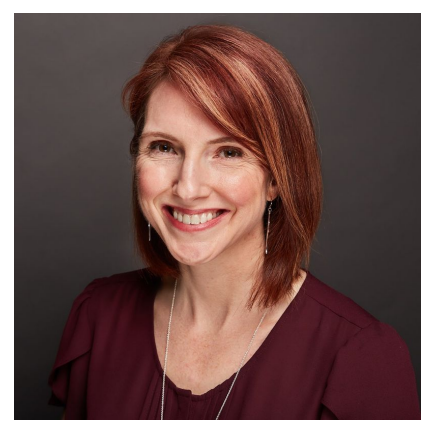

Erin Landis, ISMTE President

When I prepared my "new president" article for EON in December 2019, I included a quote by Deepak Chopra: "Even when you think you have your life all mapped out, things happen that shape your destiny in ways you might never even have imagined. The coincidences or little miracles that happen every day of your life are hints that the universe has much bigger plans for you than you ever dreamed of for yourself." I concluded that article with "Okay, Universe. Let's see what you have in store for me next."

Well. I need not explain what transpired over the next two years of my term as president of ISMTE. We all know that by the early spring of 2020 the world was on its way to navigating unprecedented disruption and change. I've touched on how the pandemic affected the scholarly communications industry in countless communications over the past 20 months-what I'd like to focus on here instead, is what the pandemic taught me about the resilience, adaptability, and connection I found within ISMTE and its members.

Buried under the deluge of submissions many of our journals faced early in the pandemic, forced to reconsider how annual and other routine meetings were to proceed, and dizzy with the sudden collision of personal obligations and work responsibilities, it would be understandable-expected even-for us to fold under the pressure. But instead, what I observed, time after time, was just how resilient our community is. At the end of the day, we found ways to make it work-whatever it was. The commitment I saw ISMTE volunteers make to the organization was awe-inspiring. Despite the swirling chaos around us, we forged ahead and ISMTE continued to operate, dare I say even excel, in the most uncertain of conditions.

We weren't just resilient. We were adaptable. ISMTE and its members pivoted at every turn, keeping an open and curious mind to how we needed to do things differently. We shifted from in-person meetings to global virtual events. Teleconferences became video conferences, ensuring we stayed connected. Our annual workshops went virtual. We amplified our webinars calendar and introduced our "Office Hours" program-all to unite our community. I am proud of just how fluid and nimble we all became; we stared down the specter of the pandemic and vowed to adjust. 
But perhaps the biggest lesson for me in all of this is the importance of connection. As many of us suddenly faced endless days of forced solitude, it became apparent, even to those introverts among us, that we still needed to see our colleagues, talk about the problems we were facing, and share the solutions we had uncovered. Having the honor of serving as president during this time, I was keenly aware of how connected our ISMTE community is. I was proud to call ISMTE my professional home, as I have since the beginning. We may be miles apart and work on journals of varied disciplines, but we are all connected by our common desire to excel at our contribution to the scientific process.

I am deeply grateful for the tremendous support I received during my presidencyfrom the board of directors and committee members to Donna Blake-Weems, our executive director, and to you, our ISMTE members. So too am I thankful for the continued contributions of our Corporate Members and events sponsors-their commitment in these financially tight times did not go unnoticed. It was through this support that I met so many wonderful people, many of whom I'm now lucky to count as friends.

As Meghan McDevitt, ISMTE's incoming president, prepares to take the helm, I can think of no more capable, thoughtful, and committed person to lead ISMTE through the next two years. Although I knew Meghan before joining the ISMTE board in 2018, I was lucky enough to get to know her much better, especially during the last two years. She is incredibly passionate about ISMTE and its mission; I have no doubt she will take it to new heights. I am indebted to her for her partnership during my presidency, as we waded through the complexities of leading an organization through a global pandemic.

I think this time I'll close out my article without challenging the universe. Instead, I'll accept the fact that change is inevitable, but that with resilience, adaptability, and connection, change doesn't have to scare us. I'm confident, without a shadow of a doubt, ISMTE will withstand, and even embrace, the changes that await. 